\title{
AN ANALYSIS OF GRAMMATICAL ERRORS BY THE FIRST SEMESTER STUDENTS
}

\author{
Sulistyo Adi Joko Saharjo, Ni Nyoman Nidya Trianingrum \\ Sekolah Tinggi Pariwisata Triatma Jaya \\ email: sulis_js@yahoo.com
}

\begin{abstract}
ABSTRAK
Penelitian ini berkaitan dengan analisis dari kesalahan grammar yang dilakukan oleh siswa kelasVIII (delapan) di SMP Negeri 1 Kuta Utara tahun akademik 2016/2017. Peneliti tertarik dalam menganalisis jenis kesalahan karena kesalahan yang dibuat oleh siswa harus diperbaiki sehingga tidak menjadi permanen. Jumlah populasi terdiri atas 12 kelas sejumlah 384 siswa. Jumlah populasi ditentukan dengan menggunakan teknik random sampling. Jumlah siswa yang digunakan sebagai subjek penelitian yaitu sejumlah 40 siswa. Penelitian ini menggunakan desain expost facto yang diharapkan dapat menjawab rumusan masalah sebagai berikut: apa jenis kesalahan dalam tatabahasa (grammar) yang dibuat oleh siswa kelas 8 di SMP Negeri 1 Kuta Utara pada tahun akademik 2016/2017 dalam membuat direct and indirect speech. Data yang dibutuhkan untuk penelitian dikumpulkan menggunakan grammatical transformation task. Pada grammatical transformation tasks siswa diminta untuk mengubah direct speech menjadi indirect speech demikian juga sebaliknya. Hasil tersebut menunjukkan bahwa terdapat 303 kesalahan yang dibuat oleh siswa. Dari jumlah kesalahan siswa, ditemukan empat tipe kesalahan, dengan rincian 43 (14,19\%) kesalahan omission error, 29(9,57\%) kesalahan addition errors, 58(19,14\%) kesalahan malformation errors, dan173(57,09\%) kesalahan disordering errors.
\end{abstract}

Kata Kunci: Analisis kesalahan gramatikal, pidato langsung dan tidak langsung

\section{ABSTRACT}

The present study dealt with An Analysis of Grammatical Errors bythe eighth grade students of SMP Negeri 1 Kuta Utara in academic year 2016/2017. The researcher interested in analyzing kinds of errors because the errors were made by students should be corrected so not to become fossilized. The total amount of population which consisted of 12 classes were 384 students all together. The amount of population was determined by using quota random sampling technique. The number of representative students which used as subjet under study was 40 students. The present study which made use of an ex-post facto research design was intended to answer the following research questions: what kind of grammatical errors which is made by the eighth grade students of SMP Negeri 1 Kuta Utara in academic year 2016/ 2017 in constructing direct and indirect speech. The data required for the study were collected by using grammatical transformation tasks. In the grammatical transformation tasks, the students were asked to change direct speech to indirect speech or vice versa by the correct grammatical forms in the sentences. The result revealed that there were 303 errors made by the students. From the total number of students' errors, the researcher found that there were four types of errors. There were 43(14,19\%)of omission error, there were 29(9,57\%) of addition errors, there were 58(19,14\%)of malformation errors, and there were 173(57,09\%) of disordering errors. The finding of present 
study was many students who weredifficultto answerdirect and indirect speech. They lacked of knowledge and inability in mastering English grammar so many mistakes were made by them.

Key Words: Grammatical Errors Analysis, Direct and Indirect Speech.

\section{INTRODUCTION}

A language consists of words and grammar. Grammar is the formal study of the structure of a language and describes how words fit together in meaningful constructions (Williams, 2005:2). Grammar is the set of rules for speaking and writing English properly which conventions and principles, together with their exceptions, that we have stored in our heads ('internalized') as a consequence of acquiring or learning the language (Jackson, 2005:13). Grammar is often classified as a set of rule. Grammar is the study of how words and their component parts combine to form sentences.The form of grammar is fixed and absolute. It is sometime claimed that grammar is a target or goal that every speaker needs to be achieved in order to be classified as good speaker or writer of the language. In other words grammar or language structure is one of the language components that should be understood by every learner as well because without knowledge of grammar, the student will not be able to use the target language which is learned, whether in oral or written communication. The other believes that teacher must give more attention on grammar. Grammar is a part of language learning that is important to learn; however, sometime students still get confused about direct and indirect speech. Human language can be reported in some ways. Speakers report the utterances of other speakers, or their own, in one of two ways, either directly by direct reported speech also known as quoted speech, or indirectly by indirect reported speech. Thought processes can also be reported. Quoted speech supposedly repeats the exact words spoken, whereas indirect speech reporting gives the content or even only the gist of what was said (Downing, 2006:300).

Direct and indirect speech is one sub theory of grammar. Indirect speech sometimes called reported speech which does not use quotation marks to enclose what the person says while direct speech sometimes calls quoted speech. The students should have a good mastery about direct and indirect speech since they are widely used in both spoken and written communication activities to reveal their opinion or message because direct and indirect speech is undeniably an important grammatical feature that is often difficult for the students to be learnt.

According to the above fact, the researcher is highly motivated to measure the understanding of students' grammar in various way and in the sub theories of grammar using direct and indirect speech.Based on the background of the study the researcher intends to study the following research question what kind of grammatical errors which is made by the eighth grade students of SMP Negeri 1 Kuta Utara in academic year 2016/ 2017in constructing direct and indirect speech 
This study investigates how well the students have acquired the forms and functions of direct and indirect speech. This study has a purpose to analyze grammatical error made by the eighth grade students of SMP Negeri 1 Kuta Utara in academic year 2016/ 2017in constructing direct and indirect speech.

\section{RESEARCH METHOD}

Each research should have a research design, strategy or plan in conducting the research. A good design, one in which the components work harmoniously together, promote efficient and successfull functioning (Maxwell, 2005:2). In this study to approve present study was an error analysis of direct and indirect speech, it made use of an ex post facto or nonexperimental research design. This type of research design is defined a systematic empirical inquiry in which the researcher does not have control if independent variables because their manifestations have already taken place.

Ex post facto research is a method that can also be used instead of an experiment, to test hypotheses about cause and effect in situations where it is unethical to control or manipulate the dependent variable (Cohen et al., 2007:264). Ex post facto is a method of teasing out possible antecedents of events that have happened and cannot, therefore be controlled, engineered or manipulated by the investigator.

The researcher uses ex post facto research design in order to measure students' ability and to analyze the errors made by the students. Error analysis as a descriptive study is designed to obtain information about subject's ability, in this case, the ability to construct direct and indirect speech. The direct and indirect speech which had been learnt and obtained by the learners were certainly in relation with teaching material stipulated by the English curriculum. Lack of control of some extraneous independent variable has been widely acknowledged as the inherent pitfall or drawback of an ex post facto study.Despite of the fact in the spare of language education, the result of an ex post facto study can still provide and contribute some significance.

In collecting data concerning the characteristics of a group of individuals or objects, such as the heights and weights of students in a university or the numbers of defective and nondefective bolts produced in a factory on a given day, it is often impossible or impractical to observe the entire group, especially if it is large, instead of examining the entire group called the population. The population of this study consistedof the eighth grade students of SMP Negeri 1 Kuta Utara in academic year 2016/ 2017. There were 384 students which consisted of 12 classes. In each class consisted about 32 students. The classes then were renamed as A, B, C, D, E, F, G, $\mathrm{H}, \mathrm{I}, \mathrm{J}, \mathrm{K}$, and $\mathrm{L}$. In order to make a brief report of the research, the number of the population should be decreased. The decreased number of population is then called sample.

A sample is a part of the population from which we actually collect information, we use a sample to draw conclusions about entire population (Moore, 2010:202). The 
selection of the sample from the subject used random sampling method. Random sampling method allows the researcher to pick the sample randomly. Sampling method describes the rules by which elements of a given population are selected for the sample. If these rules depend on chance, it is thus random sampling method, this means that each element in the population can be part of the sample with a given probability greater than zero (Rasch, 2011:134). The subjects of the present which total 40 students were considered to be representative enough.

The preparation of valid and reliable research instrument determines the validity and reliablility of the data which are required for the study. The instrument in this study was in the form of grammatical transformation. Kind of test that was used in this study was grammatical transformation tasks. There consisted of 40question, in this case the students had to change type of direct speech into indirect speech or from indirect speech into direct speech.Brown (2004:226) argues that grammatical transformation tasks are easy to administer and are therefore practical, quite high in scorer reliability and arguably tap into knowledge of grammatical forms that will be performed through writing. The item should be meaningful and free of irrelevant materials, it should give clear directions to answer the test and each test item should be clear, specific, and brief.

In order to answer the research question under investigation, the researcherdesigned valid and reliableresearch instruments. In this case, the researchinstrumentin the form ofgrammatical transformation.
Theresearcher examined theschedule todeterminethe exactschedule ofthe study. The data is collectedin the classroom. Implementation of theteststo studentswould be conductedby theresearcher inorder to reduce thepossibility ofdisorderingby thestudents. The studentsanswerthe testwith atime allocationprovided. The researcherthenwould collectdatain the form ofthe answer sheetof each student.

To answer thestatementofthe researchquestion, the data would be gatheredand thenanalyzed. Erroranalysis proceduresin direct andindirectspeechas follows: first, the data obtainedare collected, thenthe datais checkedandanalyzed to finderrorsineach answer. Errors thatoccurare classifiedinto thegrammatical errors. Lee in Heift (2007:97) state that learners may omit necessary items or add unnecessary ones.Process

ofidentificationandclassification oferrorsis verydifficult, especiallyin identifyinggrammatical errors; therefore,the overallgrammatical errorsare identifiedandclassified bylevelinto an erroradding(EoA), the errormalformations(EoMal), errors ofomission(EoM), and errors of disordering(EOR). According to Ellis (2005:65), after identifying, describing and explaningthe errors, each kind of errors are calculated into percentage. Here is the pattern:

$\%$ Each Error $=\frac{\text { Total Each Error }}{\text { Total Error }} \times 100 \%$

\% Each Error : Percentage of each error Total Each Error : Total error of each category committed by the whole samples 
Total Error : Total error committed by the whole samples

\section{FINDING}

\section{Identification of Errors}

The purpose of the study is to answer the statement of research question, in which the research question is to what kind of grammatical errors which is made by the students in constructing direct and indirect speech.

The data was analyzed in the following procedure. Firstly, the obtained data were checked thoroughly and critically in order to identify and recognize all types of grammatical errors that were committed by the samples. The whole grammatical errors were classified on the basis of global levels into: errors of omission, errors of addition, errors of malformation, and errors of disordering. The classification was arranged through form of table.The percentages of each type of grammatical errors were computed in order to figure out the extent or the significance of the committed grammatical errors. The amount of students' errors was identified from grammatical transformation task. Total of students' errors can be tabulated as follow.

Table 1. Tabulation of Students' Errors in Changing Direct and Indirect Speech or Vice Versa.

\begin{tabular}{|c|c|c|c|c|c|}
\hline No. & $\begin{array}{l}\text { Name } \\
\text { Subject }\end{array}$ & $\begin{array}{l}\text { Total } \\
\text { Error } \\
\end{array}$ & No. & $\begin{array}{l}\text { Name } \\
\text { Subject }\end{array}$ & $\begin{array}{l}\text { Total } \\
\text { Error } \\
\end{array}$ \\
\hline 1. & 1. & 6 & 21. & 21. & 15 \\
\hline 2. & 2. & 6 & 22. & 22. & 13 \\
\hline 3. & 3. & 8 & 23. & 23. & 3 \\
\hline 4. & 4. & 7 & 24. & 24. & 7 \\
\hline 5. & 5. & 3 & 25. & 25. & 12 \\
\hline 6. & 6. & 4 & 26. & 26. & 11 \\
\hline
\end{tabular}

\begin{tabular}{cccccc}
7. & 7. & 6 & 27. & 27. & 12 \\
8. & 8. & 4 & 28. & 28. & 6 \\
9. & 9. & 5 & 29. & 29. & 17 \\
10. & 10. & 5 & 30. & 30. & 8 \\
11. & 11. & 6 & 31. & 31. & 7 \\
12. & 12. & 8 & 32. & 32. & 3 \\
13. & 13. & 5 & 33. & 33. & 15 \\
14. & 14. & 13 & 34. & 34. & 13 \\
15. & 15. & 6 & 35. & 35. & 6 \\
16. & 16. & 6 & 36. & 36. & 6 \\
\hline 17. & 17. & 17 & 37. & 37. & 6 \\
18. & 18. & 17 & 38. & 38. & 4 \\
19. & 19. & 7 & 39. & 39. & 15 \\
20. & 20. & 12 & 40. & 40. & 16 \\
\hline
\end{tabular}

The result revealed that there were 303 errors made by the students of English From the total number of students errors, the researcher found that there were four types of errors, when the students were asked to change direct speech to indirect speech or vice versathrough the grammatical transformation tasks.

The whole grammatical errors that were committed by the students could be identified and classified on the basis of global levels.

Table 2. Tabulation of Data Showing The

\begin{tabular}{ccccc}
\multicolumn{5}{c}{ Errors } \\
\hline \multirow{4}{\text{Sam}}{$\begin{array}{c}\text { Classifications of Grammatical Errors in Global } \\
\text { Levels }\end{array}$} & $\begin{array}{c}\text { Errors } \\
\text { of } \\
\text { Omissio } \\
\mathrm{n}\end{array}$ & $\begin{array}{c}\text { Errors } \\
\text { of } \\
\text { Additio } \\
\mathrm{n}\end{array}$ & $\begin{array}{c}\text { Errors of } \\
\text { Malformat } \\
\text { ion }\end{array}$ & $\begin{array}{c}\text { Errors of } \\
\text { Disorderin } \\
\mathrm{g}\end{array}$ \\
\hline 1 & 1 & - & 3 & 2 \\
2 & 2 & 1 & - & 3 \\
3 & 1 & - & 2 & 5
\end{tabular}




\begin{tabular}{|c|c|c|c|c|}
\hline 4 & 3 & - & - & 4 \\
\hline 5 & 1 & - & 1 & 1 \\
\hline 6 & 2 & 1 & - & 1 \\
\hline 7 & 1 & - & 3 & 2 \\
\hline 8 & 1 & - & 1 & 2 \\
\hline 9 & 1 & - & 1 & 3 \\
\hline 10 & 1 & - & - & 4 \\
\hline 11 & 3 & 1 & - & 2 \\
\hline 12 & 1 & - & - & 7 \\
\hline 13 & - & - & 2 & 3 \\
\hline 14 & 5 & - & 2 & 6 \\
\hline 15 & 1 & - & - & 5 \\
\hline 16 & 3 & 2 & - & 1 \\
\hline 17 & 1 & 3 & & 13 \\
\hline 18 & 4 & 1 & 6 & 6 \\
\hline 19 & 2 & - & - & 5 \\
\hline 20 & 6 & 1 & - & 5 \\
\hline 21 & 5 & 2 & 5 & 3 \\
\hline 22 & 3 & 2 & & 8 \\
\hline 23 & 1 & 1 & - & 1 \\
\hline 24 & 1 & - & 3 & 3 \\
\hline 25 & 3 & 2 & - & 7 \\
\hline 26 & 2 & - & 3 & 6 \\
\hline 27 & 3 & - & 3 & 6 \\
\hline 28 & 3 & 2 & - & 1 \\
\hline 29 & 1 & 3 & & 13 \\
\hline 30 & 1 & - & 2 & 5 \\
\hline 31 & 3 & - & - & 4 \\
\hline 32 & 1 & - & 1 & 1 \\
\hline 33 & 5 & 2 & 5 & 3 \\
\hline 34 & 3 & 2 & - & 8 \\
\hline 35 & 1 & - & 3 & 2 \\
\hline 36 & 2 & 1 & - & 3 \\
\hline 37 & 1 & - & 3 & 2 \\
\hline 38 & 1 & - & 1 & 2 \\
\hline 39 & 1 & - & 6 & 8 \\
\hline \multirow[t]{2}{*}{40} & 2 & 2 & 5 & 7 \\
\hline & 43 & 29 & 58 & 173 \\
\hline
\end{tabular}

There were 43 errors of omission (EoM), 29 errors of addition (EoA), 58 errors of malformation (EoMal), and 173 errors of disordering (EoR). Thus, there were 303 grammatical errors which were committed by the students in constructing direct and indirect speech or vice versa. After classifying the data into four errors the researcher then calculated the data into comparative percentages of grammatical errors. According to Ellis (2005:65) the calculation could be computed as follow: $\%$ Each Error $=\frac{\text { Total Each Error }}{\text { Total Error }} \times 100 \%$ $\% \mathrm{EoM}=\frac{43}{303} \times 100 \%=14.19 \%$ $\% \mathrm{EoA}=\frac{29}{303} \times 100 \%=9.57 \%$

$\%$ EoMal $=\frac{58}{303} \times 100 \%=19.14 \%$

$\% \mathrm{EoR}=\frac{173}{303} \times 100 \%=57.09 \%$

It was clearly revealed that (1) there were 43errors of omission (EoM) committed by the subjects that were represented by $14.19 \%$. (2) There were 29 errors of addition (EoA) committed by the subjects that were represented by $9.57 \%$. (3) There were 58 errors of malformation (EoMal) committed by the subjects that were represented by $19.14 \%$. (4) There were 173 errors of disordering (EoR) committed by the subjects that were represented by 57.09\% inconstructingdirect and indirect speech or vice versa.

The data analysis leads to the discussion of the research findings of the present study. The data of the present investigation were analyzed by using four 
kind of errors. Dealing with the basis of four kind of errors, the finding pointed out that EoR $(57.09 \%)$ was highest position, EoMal (19.14\%) dominated second position, EoM $(14.19 \%)$ was the third position, and EoA $(9.57 \%)$ was the last position made by the students.It showed the real ability of the students in changing direct and indirect speech or vice versa. In general these findings proved that the studentsdid not master the grammar role yet, especially in constructing direct and indirect speech. The errors were committed almost by all of the students. It showed that they needed more attention in grammar comprehension; otherwise, they would face problems in expressing grammatical ability. Furthermore, they will face a big problem in the final examination.

\section{Discussion of the Findings}

The result of the students' errors in using direct and indirect speech of the students was clearly showed. The totals number of students' errors could be classified into kinds of errors. From the total number of students errors, the researcher found that there were four kinds of errors.

The result of the errors analysis of the students in constructing direct and indirect speech figured out that $57.09 \%$ of the errors were produced in the field of disordering error (EoR). The errors of disordering were mostly occurred when the students were ordered to complete a certain kinds. There were some examples of disordering errors made by the students, they were as follows:

- Andira said that her English might improve quickly next week.
- He told her that give him the key now.

- She said,'I was reading the day before".

- He asked him,"What time it is?".

There are $19.14 \%$ errors in the field of malformations (EoMal). There are some examples of malformations errors made by the students, they are as follows:

- Orlano said that wall ask the teacher to explain the differences between quoted speech and reported spech following month."

- She said that she had worked here since she left her last jos.

- The social science teacher asked,'Why wer you absen yesterday?"

There are $14.19 \%$ omissions errors (EoM). There were some examples of omission errors made by the students, they were as follows:

- Della said that she went to the library with the following two days.

- Jason asked me if I was coming with him.

- "Fill in the form, Sir," receptionist said.

- Eva,"I found a wallet yesterday."

There are $9.57 \%$ errors in the field of addition (EoA). There were some examples of addition errors made by the students, theywere as follows:

If you had moved one more inch, I would shoot you.

- They said that they hadn't seen Ari to that week.

- He asked me if I'll have finish reading the newspaper.

- He said, "I will have finished this is a paper by tomorrow."

- "Sit down please, Caron" he said.

The findings of the error analysis appear to be line with existing schools of 
thoughts, theories and empirical evidences of error analysis (EA).

In the process of classifying the type errors, the researcher was sure that she might make some errors. The findings of this investigation might not have an excellent. The findings of this study were considered to have rather restricted validity and reliability because of two main reasons. Firstly, the process of identifying and classifying grammatical errors had been widely admitted to be very difficult. In the process of identifying and classifying the grammatical errors made by the subjects under study, the researcher could inevitably get rid of making errors. Secondly, this study used ex post facto research design which had been widely characterized as inherent of some extraneous independent variable which might contaminate the validity and reliability of the established research finding. The findings of the study were regarded to have rather limited validity and reliability because the degree of the validity and reliability of the research instrument as well as the procedures of the collect data.

\section{Conclusion}

In order to answer the research question, the required data of the investigation were gathered. The research question which is related to the number of grammatical errors made by the students was answered. At the end of the overall process of the accomplishment of this study, some conclusion were as follows:

1. There were 173errors of disordering (EoR) committed by the samples that were represented by $57.09 \%$.
2. There were 58 errors of malformation (EoMal) committed by the samples that were represented by $19.14 \%$.

3. There were 43errors of omission (EoM) committed by the samples that were represented by $14.19 \%$.

4. There were 29errors of addition (EoA) committed by the samples that were represented by $9.57 \%$ in their direct and indirect speech construction or vice versa.

In general these findings proved that the students did not master the grammar role yet, especially in constructing direct and indirect speech.

The errors were committed almost by all of the samples. It showed that they needed more attention in grammar comprehension. The findings of this study have to be carefully generalized to the whole population as based in doing instruction. The whole grammatical errors committed by the samples could possibly be induced by intralingual transfer. It showed that the established research findings appeared to be corresponding with the theories and empirical evidence of errors analysis which had been reviewed to ground the undertaking of this study. When learning English, as a foreign language, the students inevitably and negatively transferred grammatical system of their mother tongue. This was due to the fact that they started learning English as a foreign language when they had already internalized, recorded or stored the system of their mother tongue in their mind.

The researcher also admitted that in the process of grammatical errors 
identification and classification, researcher could inevitably get rid of making errors. Furthermore, this study used an ex post facto research design which had been widely characterized of bearing inherent pitfalls as lacking of direct control of some extraneous independent variable which might contaminate the validity and reliability of the established research finding.

\section{REFERENCES}

Brown, H.D.(2004). Language Assessment Principles and Classroom Practices. United State: Longman.

Cohen, L., Manion, L., and Morprison, K.(2007). Reasearch Method in Education. USA:Routledge.

Downing, A., and Locke, P. (2006). English Grammar A University Course Second Edition. USA: Routledge.

Heift, T and Schulze. M. (2007). Errors and Inteligence in Computer Assisted Language Learning. New York: Routledge

Jackson, H. (2005). Good Grammar For Students. London: Sage.

Maxwell, J. (2005). Qualitative Research Design An Interactive Approach Second Edition. California: Sage Publications

Moore, S D. (2009). The Basic Practiceof Statistic. United States of America: Palgrave Macmillan.

Rasch, D., Kubinger, K., and Yanagida T.(2011). Statistics in Psychology Using $R$ and SPSS.United Kingdom: John Wiley and Sons.

Williams, J.D. (2005). The Teacher's Grammar Book.Taylor \& Francis group: Routledge. 